\title{
Nitric Oxide Inhibitory and Cytotoxic Activities of Spice Essential Oils
}

\author{
Nakuntwalai Wisidsri*, Suradwadee Thungmungmee, \\ and Warachate Khobjai
}

\begin{abstract}
Department of Thai Traditional Medicine, Thai Traditional Medicine College, Rajamangala University of Technology Thanyaburi, Pathum Thani 12130, Thailand
\end{abstract}

*Corresponding author.E-mail: nakuntwalai_w@rmutt.ac.th

https://doi.org/10.12982/CMUJNS.2019.0026

\begin{abstract}
This study aims to investigate the effects of anise oil, lemongrass oil and cassia oil on nitric oxide production from nitric oxide donor and stimulated macrophage cells. Furthermore, this study also evaluates the cytotoxic effect of essential oils on cell viability of macrophage and human colorectal cancer cells. The results showed that anise oil and lemongrass oil presented higher nitric oxide scavenging capacity by reduction of nitrite formation from NO donor with $I C_{50}$ of 406.90 and $413.50 \mu \mathrm{g} / \mathrm{ml}$. In vitro study, cassia oil presented lower NO scavenging capacity. For cellular study, lemongrass oil and cassia oil at concentration of $6.25-25 \mu \mathrm{g} / \mathrm{ml}$ and all concentration of anise oil $(6.25-100 \mu \mathrm{g} / \mathrm{ml})$ presented $\mathrm{NO}$ inhibitory activity with no cytotoxic effect of the macrophages. For the cancer cell study, lemongrass oil and cassia oil reduced cell viability of human colorectal cancer cells after 48 h of treatment with $I C_{50}$ of 77.91 and $32.72 \mu \mathrm{g} / \mathrm{ml}$, and $I C_{50}$ was better in $72 \mathrm{~h}$ of treatment with 67.96 and $21.94 \mu \mathrm{g} / \mathrm{ml}$. Nevertheless, anise oil displayed insignificant effect on HT-29 cell viability. Anethole, citral and cinnamaldehyde were identified as main composition of anise oil, lemongrass oil and cassia oil using gas chromatography-mass spectrometry (GC-MS). The results from this study suggested the different effects of essential oils on nitric oxide inhibition of in vitro and cellular study as well as the cytotoxic effect to macrophage and colorectal cancer cell. These results are beneficial for further study of anise oil, cassia oil and lemongrass oil in pharmaceuticals and natural therapies.
\end{abstract}

Keywords: Anise oil, Lemongrass oil, Cassia oil, Nitric oxide, Macrophage, Human colorectal cancer 


\section{INTRODUCTION}

Nitric oxide (NO) is one of oxidative molecule which involved in inflammatory processes and cancer development. Nitric oxide acts as a signaling molecule in the normal physiological control. However, under hypoxic conditions, NO is produced by the mitochondrial respiratory chain which can generate other reactive nitrogen species (RNS). The excess production of NO causes of oxidative stress and chronic inflammation which further associated to increase the risk of several human cancer development (Reuter et al., 2010).

Nitric oxide (NO) is accumulated in chronic inflammatory processes by phagocytic cells, including macrophages. Excessive NO interacts with $\mathrm{O}_{2}$ - to contribute cytotoxic oxidant peroxynitrite (ONOO-), which is a powerful oxidant to initiate lipid peroxidation and cleavage DNA, resulting in the risk of cancer (Choudhari et al., 2013). NO presents different roles in the development stage of cancers, including functions as a signaling molecule in the regulation of cancer formation, progression and metastasis as well as application in cancer therapy. However, high level of NO modulates matrix metalloproteinase (MMP) expression in malignant cells to support tumor cell invasion in the cancer invasive stage. This event is supported by the previous study that found the angiogenesis in tumor cell was suppressed afterwards the inhibition of nitric oxide production (Cheng et al., 2014).

Three of spice essential oils (anise oil, lemongrass oil and cassia oil) have been demonstrated the pharmacological activities. Anise oil is separated from star anise (Illicium verum Hook. fil.) and commonly used in cooking and utilization for antifungal agents in medical and food (Matan et al., 2012). Anise oil and anise seed extract also presented anti-proliferative effect on gastric cancer cells (Rahamooz-Haghighi \& Asadi, 2016).

Lemongrass oil is the volatile oil from Cymbopogon citratus D.C. (C. citratus) which has been used as a remedy for the treatment of various health conditions. In Asia and Africa, lemongrass oil has been used for pain and inflammation treatment, e.g. backache, sprains and anti-rheumatic as well as antiseptic and antitussive (Boukhatem et al., 2014). The pharmacological properties of $C$. citratus have been exhibited antimicrobial and antifungal (Adukwu et al., 2016; Liakos et al., 2016) and anti-proliferative effect on human colon carcinoma (HCT-116), breast carcinoma (MCF-7 and MDA-MB 231), ovarian carcinoma (SKOV-3 and COAV), and a normal liver cell line (WRL 68) (Halabi \& Sheikh, 2014) and HeLa and ME-180 cervical cell line (Ghosh, 2013).

Cassia oil is the volatile oil from the leaves, branches or barks of Cinnamomum cassia Blume (Lauraceae) and has been traditionally used as a spice and aromatic (Geng et al., 2011). The pharmacological activity of cassia 
oil were possessed antimicrobial (Ooi et al., 2006; Kavanaugh \& Ribbeck, 2012; Swamy et al., 2016), antioxidant (Lin et al., 2003; Yang et al., 2012), cytotoxic and mutagenic effect in human HeLa epithelioid cervical cancer, A549 lung cancer, SK-OV-3 ovarian cancer, SK-MEL-2 melanoma, XF-498 central nerve system solid tumor, and HCT-15 colon tumor cell lines (Lee et al., 2004), and anti-inflammatory (Lee et al., 2005; Pannee et al., 2014) properties.

This research proposes to investigate the effects of anise oil, lemongrass oil and cassia oil in inhibition of nitric oxide the key molecule which involving in oxidative stress, inflammation and human colorectal cancer progression. Furthermore, this research also examines cytotoxicity of anise oil, lemongrass oil and cassia oil in RAW264.7 macrophage cells and HT-29 human colorectal cancer cells.

\section{MATERIALS AND METHODS}

\section{Materials}

Anise oil, lemongrass oil and cassia oil (leaves of Cinnamomum cassia) were obtained from Thai-China Flavours and Fragrance Industry Co., Ltd., (Bangkok, Thailand).

\section{Nitric oxide (NO) radical scavenging ability of anise oil, lemongrass oil and cassia oil}

In this research, sodium nitroprusside (SNP) (Sigma-Aldrich, USA) was used as the nitric oxide donor. Specifically, $10 \mathrm{mM}$ of SNP in a phosphate buffer saline $\mathrm{pH} 7.4$ (PBS pH 7.4) solution was incubated with $1 \mathrm{ml}$ of variable concentrations of anise oil, lemongrass oil and cassia oil $(62.5,125,250,500$, $1,000 \mu \mathrm{g} / \mathrm{ml}$ ) at $25^{\circ} \mathrm{C}$ for $180 \mathrm{~min}$. Approximately $100 \mu 1$ of the testing solution was withdrawn to react with a Griess Reagent kit (Promega, USA) whereby the solution was reacted with $20 \mu \mathrm{l}$ sulfanilamide for $10 \mathrm{~min}$ and then $20 \mu \mathrm{l}$ $\mathrm{N}$-1-napthylethylenediamine dihydrochloride for another $10 \mathrm{~min}$. The reaction mixture absorbance was measured at $560 \mathrm{~nm}$ and the nitric oxide (NO) concentrations were determined as the nitrite $\left(\mathrm{NO}_{2}^{-}\right)$concentrations from the standard curve of a standard nitrite solution. The $0.2 \%$ ethanol and L-ascorbic acid were used as the negative and positive controls, respectively. The NO scavenging capacity of anise oil, lemongrass oil and cassia oil were expressed as a percentage of nitrite formation inhibition using the following formula:

$\% \mathrm{NO}_{2}$ - formation inhibition $=\left[\left(\mathrm{NO}_{2}-\right.\right.$ without essential oil $-\mathrm{NO}_{2}-$ with essential oil) $/ \mathrm{NO}_{2}$ - without essential oil] x 100 


\section{Cell culture}

RAW264.7 murine macrophage cell line and HT-29 human colorectal cancer cell line were obtained from the American Type Culture Collection (ATCC, Manassas, VA). The cells were maintained in Dulbecco's modified Eagle's medium (DMEM) (Gibco, USA) containing 10\% fetal bovine serum (Gibco, USA) and $100 \mathrm{U} / \mathrm{ml}$ penicillin and $100 \mu \mathrm{g} / \mathrm{ml}$ streptomycin (Gibco, USA) and incubated at $37^{\circ} \mathrm{C}$ in $5 \% \mathrm{CO}_{2} / 95 \%$ air humidified incubator. The RAW264.7 cell was subcultured using cell scraper twice a week and HT-29 cell was subcultured using $0.25 \%$ trypsin-EDTA (Gibco, USA) trypsinization. The cell viability was determined using $0.4 \%$ trypan blue (Sigma-Aldrich, USA) with cell viability $>85 \%$ was used in all the experiments.

\section{Determination of NO production in lipopolysaccharide (LPS)-stimulated macrophage}

The RAW264.7 murine macrophage cells at $2 \times 10^{5}$ cell $/ \mathrm{ml}$ were plated in 96-well plate for $24 \mathrm{~h}$. The plated-cell were pretreated with various concentrations of anise oil, lemongrass oil and cassia oil $(6.25,12.5,25,50$ and 100 $\mu \mathrm{g} / \mathrm{ml}$ ) and incubated for another $24 \mathrm{~h}$. The treated cells were stimulated with $1 \mu \mathrm{g} / \mathrm{ml}$ LPS and incubated for another $24 \mathrm{~h}$. The NO concentrations were determined from nitrite $\left(\mathrm{NO}_{2}^{-}\right)$in the stimulated-cell supernatant using a Griess reagent kit whereby $100 \mu \mathrm{l}$ of the supernatant was reacted with $20 \mu \mathrm{l}$ sulfanilamide for $10 \mathrm{~min}$ and then with $20 \mu \mathrm{N}$-1-napthylethylenediamine dihydrochoride for another $10 \mathrm{~min}$. The reaction mixture absorbance was measured at $560 \mathrm{~nm}$ and the nitric oxide (NO) concentrations were determined as the nitrite $\left(\mathrm{NO}_{2}-\right)$ concentrations from the standard curve of a standard nitrite solution. The treated cell with $0.02 \%$ ethanol and $100 \mu \mathrm{M}$ of dexamethasone each with $1 \mu \mathrm{g} / \mathrm{ml}$ LPS were respectively used as the negative and positive controls.

\section{Determination of cell viability of RAW264.7 murine macrophage cells}

The viability of the residual macrophage cells after the NO assay, given anise oil, lemongrass oil and cassia oil concentrations of $6.25,12.5$, 25, 50 and $100 \mu \mathrm{g} / \mathrm{ml}$, were determined by resazurin (Sigma-Aldrich, USA) reduction assay, whereby the residual cells were incubated for $2 \mathrm{~h}$ at $37^{\circ} \mathrm{C}$ in $100 \mu \mathrm{l}$ fresh DMEM containing $50 \mu \mathrm{g} / \mathrm{ml}$ resazurin. The reaction mixture absorbance was determined at 560 against $600 \mathrm{~nm}$.

\section{Determination of cell viability of HT-29 human colorectal cancer cells}

The HT-29 cells at $5 \times 10^{4}$ cells $/ \mathrm{ml}$ were plated in 96-well plates for $24 \mathrm{~h}$. The cells were treated with various concentrations of anise oil, lemongrass oil and cassia oil at a concentration of $6.25,12.5,25,50$ and $100 \mu \mathrm{g} / \mathrm{ml}$ for another 48 and 
$72 \mathrm{~h}$. The cell viability was evaluated by adding $50 \mu \mathrm{g} / \mathrm{ml}$ resazurin solution into each well. The reaction mixture absorbance was determined at 560 against $600 \mathrm{~nm}$.

The cell viability of the RAW264.7 murine macrophage and HT-29 human colorectal cancer cells were presented as percentage cell viability by using the following formula:

$$
\% \text { Cell viability }=\left[\left(\mathrm{OD}_{560}-\mathrm{OD}_{600}\right)_{\text {sample }} /\left(\mathrm{OD}_{560}-\mathrm{OD}_{600}\right)_{\text {control }}\right] \times 100
$$

\section{Analysis of essential oils}

GC-MS analysis for essential oil compositions was performed on an Agilent 7890 GC system instrument equipped with HP-5MS (5\% diphenyl 95\% dimethylpolysiloxane) column ( $30 \mathrm{~m} \times 0.25 \mathrm{~mm} \times 0.25 \mu \mathrm{m})$ and interfaced to a 5975C inert XL MSD with Triple-Axis Detector. An injection volume of $5 \mu 1$ was employed (split ratio of 20:1) injector temperature $110^{\circ} \mathrm{C}$. The column temperature was increased from $110^{\circ} \mathrm{C}$ (hold $1 \mathrm{~min}$.) to $250^{\circ} \mathrm{C}$ (hold $1 \mathrm{~min}$.) in a rate $5^{\circ} \mathrm{C} /$ min. The outlet temperature was $250^{\circ} \mathrm{C}$. Mass spectra were taken at $70 \mathrm{eV}$ and fragments from 40 to $700 \mathrm{~m} / \mathrm{z}$. MS transfer line temperature $250^{\circ} \mathrm{C}$. Identification of compounds was conducted using the database of the National Institute of Standards and Technology (NIST) library. The name, molecular weight, molecular formula, and area under the peak of the test material components were ascertained.

\section{Data analysis}

In this research, the experiments contain the $\mathrm{NO}$ scavenging ability, given anise oil, lemongrass oil and cassia oil concentration of 62.5, 125, 250, 500, 1,000 $\mu \mathrm{g} / \mathrm{ml}$; and the NO production and cell viability, given anise oil, lemongrass oil and cassia oil concentration of $6.25,12.5,25,50$ and $100 \mu \mathrm{g} / \mathrm{ml}$; and the cytotoxicity of HT-29 cells, given anise oil, lemongrass oil and cassia oil concentration of $6.25,12.5,25,50$ and $100 \mu \mathrm{g} / \mathrm{ml}$. Each experiment was carried out in triplicate. The statistical data were expressed as mean \pm standard error of mean (SEM). The negative control group (ethanol) was compared against the experimental group using one-way ANOVA with Tukey's Honestly Significant Difference (HSD) post hoc test, with the $5 \%(P<0.05)$ and $1 \%(P<0.01)$ significance levels.

\section{RESULTS}

\section{Nitric oxide scavenging ability}

This research found that NO scavenging capacity of anise oil, lemongrass oil and cassia oil were presented in the concentration of $62.5-1,000 \mu \mathrm{g} /$ $\mathrm{ml}(62.5,125,250,500,1,000 \mu \mathrm{g} / \mathrm{ml})$. In the absence of essential oils, the negative control $\left(0.2 \%\right.$ ethanol) exhibited a high $\mathrm{NO}_{2}$ - concentration while L-ascorbic acid (the positive control) inhibited the $\mathrm{NO}_{2}^{-}$formation. 
The results demonstrated that anise oil and lemongrass oil significantly reduced $\mathrm{NO}_{2}$-, achieving the scavenging performance in the range of $14.70 \pm 3.25$ $68.45 \pm 3.74 \%$ and $14.17 \pm 2.50-81.83 \pm 1.45 \%$, respectively (Figure 1); and an $\mathrm{IC}_{50}$ of 406.90 and $413.50 \mu \mathrm{g} / \mathrm{ml}$, respectively (Table 1), where $\mathrm{IC}_{50}$ is the inhibitory concentration at which the NO radicals are scavenged by $50 \%$. Cassia oil revealed the percentage $\mathrm{NO}_{2}$ - inhibition in the range of $3.44 \pm 2.19$ $14.17 \pm 2.50 \%$. The results revealed that anise oil and lemongrass oil showed higher percentage of $\mathrm{NO}_{2}$ - inhibition while cassia oil presented lower percentage of $\mathrm{NO}_{2}$ - inhibition. By comparison, L-ascorbic acid (the positive control) at $500 \mu \mathrm{g} / \mathrm{ml}$ achieved the $\mathrm{NO}_{2}$ - inhibition performance of $98.22 \pm 0.85 \%$.

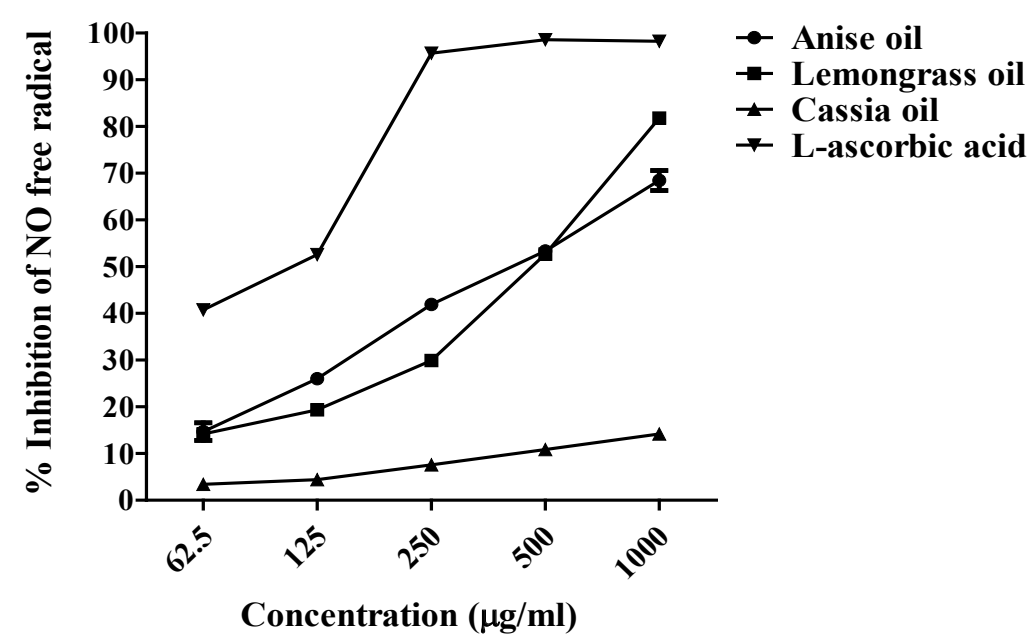

Figure 1. The NO (nitrite) inhibition efficiency (\%) under variable essential oils (anise oil, lemongrass oil and cassia oil) concentrations, compared with essential oil-free ethanol (the negative control). The values are means \pm SEM. L-ascorbic acid is used as the positive control. 
Table 1. The concentrations of anise oil, lemongrass oil, cassia oil and L-ascorbic acid at $\mathrm{NO}$ radical was scavenged $50 \%\left(\mathrm{IC}_{50}\right)$ and the concentrations of anise oil, lemongrass oil and cassia oil at NO production in LPS-stimulated RAW264.7 macrophage cells were inhibited 50\% $\left(\mathrm{IC}_{50}\right)$.

\begin{tabular}{lcc}
\hline Testing compound & $\begin{array}{c}\mathbf{I C}_{\mathbf{5 0}} \text { of NO free radical } \\
\text { scavenging } \\
(\boldsymbol{\mu g} / \mathbf{m l})\end{array}$ & $\begin{array}{c}\mathbf{I C}_{\mathbf{5 0}} \text { of NO inhibition in } \\
\mathbf{L P S}-\mathbf{s t i m u l a t e d ~ R A W 2 6 4 . 7} \\
(\boldsymbol{\mu g} / \mathbf{m l})\end{array}$ \\
\hline Anise oil & 406.90 & $\mathrm{~N} / \mathrm{A}$ \\
Lemongrass oil & 413.50 & 23.95 \\
Cassia oil & $\mathrm{N} / \mathrm{A}$ & 11.84 \\
L-ascorbic acid & 72.00 & - \\
\hline
\end{tabular}

Nitric oxide inhibition and cell viability of LPS-stimulated RAW264.7 macrophage cells

Nitric oxide is commonly parameter which used as a marker for macrophage activation. In this research, the RAW264.7 macrophage cells were treated with anise oil, lemongrass oil and cassia oil of variable concentrations $(6.25,12.5$, 25,50 and $100 \mu \mathrm{g} / \mathrm{ml}$ ) for $24 \mathrm{~h}$ prior to stimulate with $1 \mu \mathrm{g} / \mathrm{ml}$ LPS. Furthermore, $0.02 \%$ ethanol and $100 \mu \mathrm{M}$ of dexamethasone each with $1 \mu \mathrm{g} / \mathrm{ml}$ LPS were respectively used as the negative and positive controls. In Figure 2a, the experimental results demonstrated that the nitrite $\left(\mathrm{NO}_{2}^{-}\right)$concentration in the LPS-stimulated

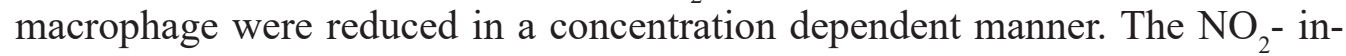
hibition was presented with a higher performance in cassia oil-treated cells.

In Figure 2b, the cell viability of lemongrass oil- and cassia oil-treated cells are significantly reduced where the concentration of lemongrass oil and cassia oil reached $50 \mu \mathrm{g} / \mathrm{ml}$ while the cell viability of anise oil-treated cells was similar to that of control $(0.02 \%$ ethanol). However, given the noncytotoxicity of essential oils, the essential oil-treated cells could achieve high NO inhibition performance (lower nitrite concentrations) with the cell viability was similar to the control $(0.02 \%$ ethanol). Therefore, $\mathrm{NO}$ inhibition performance with non-cytotoxicity was presented at a concentration of $6.25,12.5$ and $25 \mu \mathrm{g} / \mathrm{ml}$ of lemongrass oil- and cassia oil-treated cells.

Anise oil significantly reduced $\mathrm{NO}_{2}{ }^{-}$, achieving the $\mathrm{NO}$ inhibition performance with non-cytotoxicity in the range of $18.69 \pm 0.5-41.12 \pm 0.67 \%$ with concentration of $6.25,12.5,25,50$ and $100 \mu \mathrm{g} / \mathrm{ml}$. Lemongrass oil and cassia oil significantly reduced $\mathrm{NO}_{2}$, achieving the $\mathrm{NO}$ inhibition performance with non-cytotoxicity in the range of $6.76 \pm 1.74-47.59 \pm 2.15 \%$ and $12.79 \pm 0.34-80.49 \pm 0.34 \%$, respectively (Figure $2 \mathrm{a}$ ). $\mathrm{An} \mathrm{IC}_{50}$ of lemongrass oil 
and cassia oil were 23.95 and $11.84 \mu \mathrm{g} / \mathrm{ml}$, respectively (Table 1 ), where $\mathrm{IC}_{50}$ is the inhibitory concentration at which the NO is inhibited by $50 \%$. By comparison, dexamethasone (the positive control) at $100 \mu \mathrm{M}$ achieved the NO inhibitory performance of $64.50 \pm 0.85 \%$.
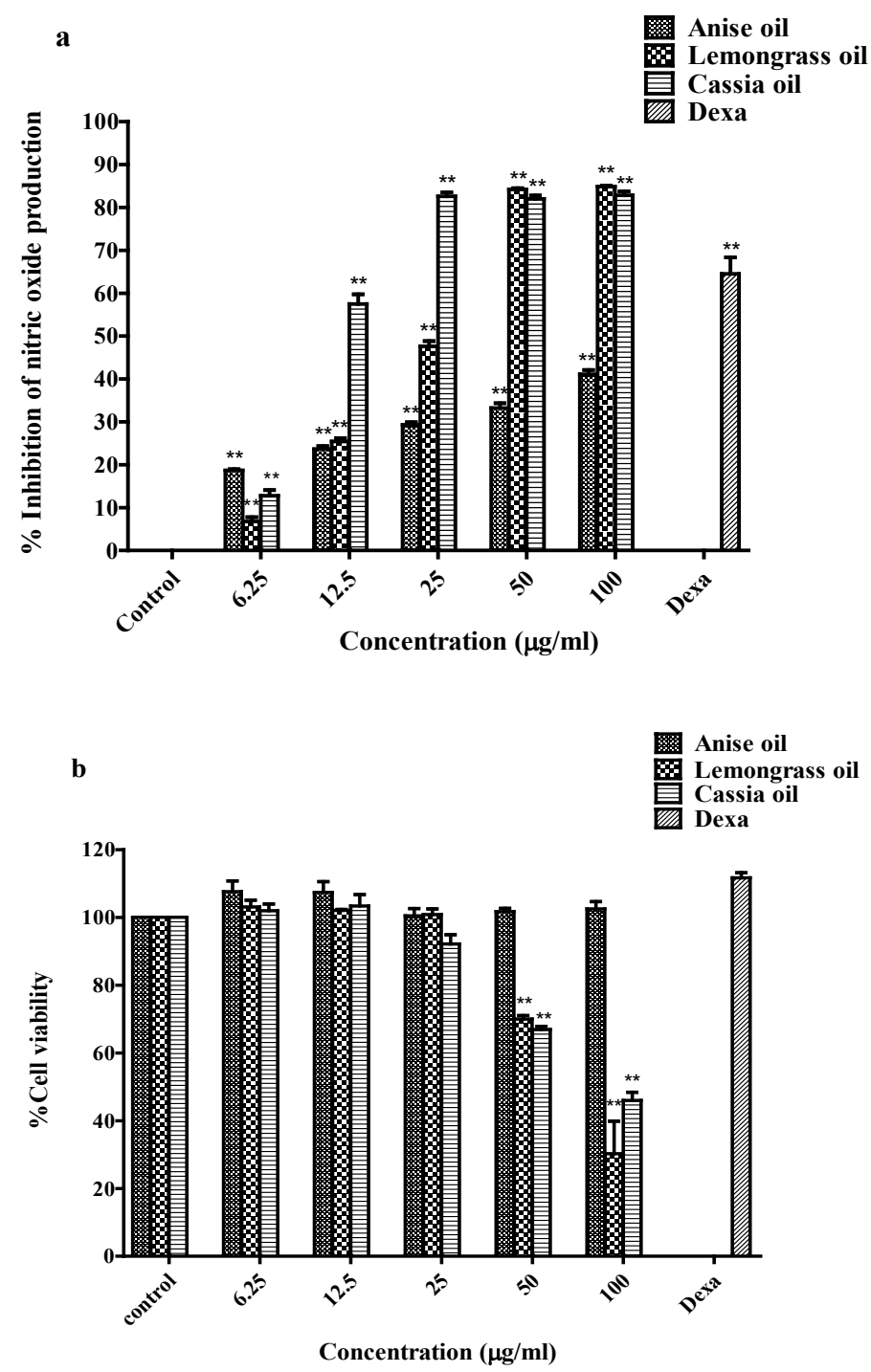

Figure 2. The effects of variable anise oil, lemongrass oil and cassia oil concentrations in $1 \mu \mathrm{g} / \mathrm{ml}$ LPS-stimulated RAW264.7 macrophage: (a) nitrite concentrations (NO production), (b) cell viability. The values are means \pm SEM and $* *$ denote $P<0.01 .0 .02 \%$ ethanol and $100 \mu \mathrm{M}$ of dexamethasone are respectively used as the negative and positive controls. 


\section{Cell viability of HT-29 human colorectal cancer cells}

In this research, the HT-29 human colorectal cancer cells were treated with anise oil, lemongrass oil and cassia oil of variable concentrations (6.26, $12.5,25,50$ and $100 \mu \mathrm{g} / \mathrm{ml}$ ) for $48 \mathrm{~h}$ and $72 \mathrm{~h}$. In addition, $0.02 \%$ ethanol was used as negative control. The reduction of cell viability presented cytotoxicity performance of the spice essential oils to the human colorectal cancer cells. In Figure 3, the results revealed that the cell viability of lemongrass oil- and cassia oil-treated cell were reduced in a concentration dependent manner.

HT-29 human colorectal cancer cells were treated with the spice essential oils for 48 and $72 \mathrm{~h}$. The cell viability was reduced significantly in lemongrass oil- and cassia oil-treated cells. Anise oil treated-cell affected insignificantly to HT-29 cell viability.

Lemongrass oil-treated cell for $48 \mathrm{~h}$ presented significant cytotoxicity at concentrations of 50 and $100 \mu \mathrm{g} / \mathrm{ml}$, achieving the reduction of the cell viability in the range of $35.13 \pm 8.08-69.08 \pm 0.49 \%$, compared with the negative control $(0.02 \%$ ethanol). The cytotoxicity of lemongrass oil treated-cell was presented with a higher performance in $72 \mathrm{~h}$. The cell viability of lemongrass oil-treated cell for $72 \mathrm{~h}$ were lower than that of $48 \mathrm{~h}$ treated-cell with presented significantly cytotoxicity at 25,50 and $100 \mu \mathrm{g} / \mathrm{ml}$, achieving the reduction of the cell viability in the range of $29.58 \pm 5.21-73.44 \pm 3.11 \%$. However, the cell viability is not significantly different between 48 and $72 \mathrm{~h}$ of treatment (Figure 3). An $\mathrm{IC}_{50}$ of lemongrass oil-treated cell are 77.91 and $67.96 \mu \mathrm{g} / \mathrm{ml}$ for 48 and $72 \mathrm{~h}$ of treatment, respectively, where $\mathrm{IC}_{50}$ is the concentration at which the cell viability is reduced by $50 \%$ (Table 2 ).

The results demonstrated that the cytotoxicity was presented with a higher performance in cassia oil-treated cell. Cassia oil-treated cell for $48 \mathrm{~h}$ and $72 \mathrm{~h}$ presented cytotoxicity at a concentration of $12.5,25,50$ and $100 \mu \mathrm{g} / \mathrm{ml}$. After treating cell for $48 \mathrm{~h}$, the cell viability of HT-29 cells was significantly reduced where compared with the negative control in the range of $25.29 \pm 8.94$ $54.88 \pm 11.52 \%$. Cassia oil-treated cell for $72 \mathrm{~h}$ at a similar concentration of $48 \mathrm{~h}$ $(25,50$ and $100 \mu \mathrm{g} / \mathrm{ml})$ presented a reduction of cell viability in the range of $6.59 \pm 3.31-47.46 \pm 13.306 \%$ (Figure 3 ). The cytotoxicity was presented with a higher performance in $72 \mathrm{~h}$ of cassia oil treated-cell, however, the results were not significantly different between 48 and $72 \mathrm{~h}$ of treatment. $\mathrm{An}_{\mathrm{IC}}$ of cassia oil-treated cell for 48 and $72 \mathrm{~h}$ were 32.72 and $21.94 \mu \mathrm{g} / \mathrm{ml}$, respectively (Table 2). 


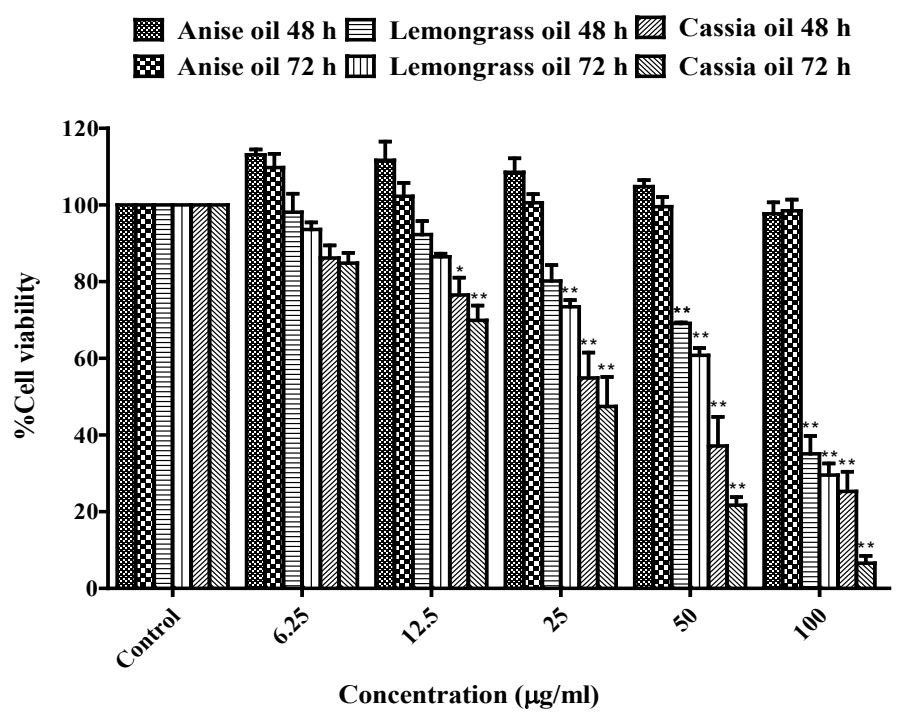

Figure 3. The effects of variable anise oil, lemongrass oil and cassia oil concentrations treated cell for 48 and $72 \mathrm{~h}$ on the cell viability of HT29 human colorectal cancer cells. The values are means \pm SEM. ${ }^{*}$ and ** respectively denote $P<0.05$ and $P<0.01 .0 .02 \%$ ethanol are used as the negative control.

Table 2. The concentrations of anise oil, lemongrass oil, cassia oil at HT-29 cell viability was reduced $50 \%\left(\mathrm{IC}_{50}\right)$.

\begin{tabular}{lcc}
\hline \multirow{2}{*}{ Test compound } & IC $_{\mathbf{5 0}}$ value of cytotoxicity $(\boldsymbol{\mu g} / \mathbf{m l})$ \\
\cline { 2 - 3 } & $\mathbf{4 8} \mathbf{~ h}$ & $\mathbf{7 2} \mathbf{~ h}$ \\
\hline Anise oil & $\mathrm{N} / \mathrm{A}$ & $\mathrm{N} / \mathrm{A}$ \\
Lemongrass oil & 77.91 & 67.96 \\
Cassia oil & 32.72 & 21.94 \\
\hline
\end{tabular}

Note: N/A (not available).

\section{Compositions of anise oil, lemongrass oil and cassia oil}

Chemical analysis of the components of anise oil, lemongrass oil and cassia oil by GC/MS led to identification by 13, 22 and 6 components, respectively. The main component of anise oil was anethole (95.72\%), the main component of lemongrass oil was citral $(47.91 \%)$ and $\beta$-citral $(44.90 \%)$, and the main component of cassia oil was cinnamaldehyde (99.31\%) (Table 3). 
Table 3. Chemical compositions of anise oil, lemongrass oil and cassia oil.

\begin{tabular}{|c|c|c|c|c|}
\hline $\mathbf{R T}^{\mathbf{a}}$ & Chemical compositions & $\begin{array}{l}\text { \%of total } \\
\text { area }\end{array}$ & $\mathbf{M F}^{\mathbf{b}}$ & MW $^{\mathbf{c}}$ \\
\hline \multicolumn{5}{|c|}{ Anise oil } \\
\hline 4.14 & 1,6-Octadien-3-ol, 3,7-dimethyl- & 0.35 & $\mathrm{C}_{10} \mathrm{H}_{18} \mathrm{O}$ & 154 \\
\hline 5.52 & $\begin{array}{l}\text { 3-Cyclohexen-1-ol, 4-methyl } \\
\text {-1-(1-methylethyl)-, (R)- }\end{array}$ & 0.03 & $\mathrm{C}_{10} \mathrm{H}_{18} \mathrm{O}$ & 154 \\
\hline 6.00 & Estragole & 1.23 & $\mathrm{C}_{10} \mathrm{H}_{12} \mathrm{O}$ & 148 \\
\hline 7.22 & Benzaldehyde, 4-methoxy- & 0.51 & $\mathrm{C}_{8} \mathrm{H}_{8} \mathrm{O}_{2}$ & 136 \\
\hline 9.49 & Anethole & 95.72 & $\mathrm{C}_{10} \mathrm{H}_{12} \mathrm{O}$ & 148 \\
\hline 9.73 & $\alpha$-Cubebene & 0.05 & $\mathrm{C}_{15} \mathrm{H}_{24}$ & 204 \\
\hline 9.87 & $\begin{array}{l}\text { 2-Propanone, 1-(4-methoxyphe- } \\
\text { nyl)- }\end{array}$ & 0.10 & $\mathrm{C}_{10} \mathrm{H}_{12} \mathrm{O}_{2}$ & 164 \\
\hline 10.70 & Caryophyllene & 0.22 & $\mathrm{C}_{15} \mathrm{H}_{24}$ & 204 \\
\hline 10.96 & trans- $\alpha$-Bergamotene & 0.20 & $\mathrm{C}_{15} \mathrm{H}_{24}$ & 204 \\
\hline 12.36 & $\begin{array}{l}\text { 1H-Cycloprop[e]azulene, } \\
\text { 1a,2,3,5,6,7,7a,7b-octahydro-1, } \\
\text { 1,4,7-tetramethyl-, [1aR- } \\
(1 \mathrm{a} \alpha, 7 \alpha, 7 \mathrm{a} \beta, 7 \mathrm{~b} \alpha)]-\end{array}$ & 0.05 & $\mathrm{C}_{15} \mathrm{H}_{24}$ & 204 \\
\hline 13.01 & $\begin{array}{l}\text { 1H-1,2,3,4-Tetrazole-1,5-diamine, } \\
\text { N(1)-[(2-ethoxy-3-methoxyphe- } \\
\text { nyl)methyl]- }\end{array}$ & 0.23 & $\mathrm{C}_{11} \mathrm{H}_{16} \mathrm{~N}_{6} \mathrm{O}_{2}$ & 264 \\
\hline 13.26 & 4-Hydroxybenzamide & 0.05 & $\mathrm{C}_{11} \mathrm{H}_{16} \mathrm{~N}_{6} \mathrm{O}_{2}$ & 264 \\
\hline 13.75 & Nerolidol & 0.07 & $\mathrm{C}_{15} \mathrm{H}_{26} \mathrm{O}$ & 222 \\
\hline 14.20 & 1-Adamantyl fluoroformate & 0.03 & $\mathrm{C}_{18} \mathrm{H}_{28} \mathrm{O}_{2}$ & 276 \\
\hline 15.85 & $\begin{array}{l}\text { Cyclooctane, 1,5-ddimethyl-2, } \\
\text { 6-bis(methylene)- }\end{array}$ & 0.03 & $\mathrm{C}_{15} \mathrm{H}_{24} \mathrm{O}$ & 220 \\
\hline 16.34 & 1, Z-5, E-7-Dodecatriene & 0.06 & $\mathrm{C}_{15} \mathrm{H}_{26} \mathrm{O}$ & 222 \\
\hline
\end{tabular}

Note: a Retention time (min); ${ }^{b}$ Molecular formula; ${ }^{c}$ Molecular weight. 
Table 3. Continued.

\begin{tabular}{|c|c|c|c|c|}
\hline $\mathbf{R T}^{\mathrm{a}}$ & Chemical compositions & $\begin{array}{c}\text { \%of total } \\
\text { area }\end{array}$ & $\mathbf{M F}^{\mathbf{b}}$ & MW $^{\mathbf{c}}$ \\
\hline \multicolumn{5}{|c|}{ Lemongrass oil } \\
\hline 6.32 & $\beta$-citral & 44.90 & $\mathrm{C}_{10} \mathrm{H}_{16} \mathrm{O}$ & 152 \\
\hline 5.33 & Santolina epoxide & 0.04 & $\mathrm{C}_{10} \mathrm{H}_{16} \mathrm{O}$ & 152 \\
\hline 5.43 & 3-Octyne & 0.43 & $\mathrm{C}_{10} \mathrm{H}_{16} \mathrm{O}$ & 152 \\
\hline 5.78 & 1,4-Heptadiene, 3-methyl- & 0.05 & $\mathrm{C}_{10} \mathrm{H}_{16} \mathrm{O}$ & 152 \\
\hline 7.28 & $\begin{array}{l}\text { 4-Hexen-1-ol, 2-ethenyl-2-5- } \\
\text { dimethyl- }\end{array}$ & 3.05 & $\mathrm{C}_{10} \mathrm{H}_{18} \mathrm{O}$ & 154 \\
\hline 7.43 & Citral & 47.91 & $\mathrm{C}_{10} \mathrm{H}_{16} \mathrm{O}$ & 152 \\
\hline 7.80 & 3-Ethyl-1,5-octadiene & 0.17 & $\mathrm{C}_{10} \mathrm{H}_{16} \mathrm{O}$ & 152 \\
\hline 7.89 & Anethole & 0.17 & $\mathrm{C}_{10} \mathrm{H}_{12} \mathrm{O}$ & 148 \\
\hline 8.16 & 2-Propenal, 3-phenyl- & 0.20 & $\mathrm{C}_{9} \mathrm{H}_{8} \mathrm{O}$ & 132 \\
\hline 9.67 & Geranyl acetate & 1.00 & $\mathrm{C}_{12} \mathrm{H}_{20} \mathrm{O}_{2}$ & 196 \\
\hline 9.74 & $\begin{array}{l}\text { 4-Hexen-1-ol, 5-methyl-2- } \\
\text { (1-methylethenyl)-, acetate }\end{array}$ & 0.44 & $\mathrm{C}_{12} \mathrm{H}_{20} \mathrm{O}_{2}$ & 196 \\
\hline 9.95 & $\begin{array}{l}\text { 1,6,10-Dodecatrien-3-ol, } \\
\text { 3,7,11-trimethyl-, [S-(Z)]- }\end{array}$ & 0.06 & $\mathrm{C}_{15} \mathrm{H}_{24} \mathrm{O}$ & 220 \\
\hline 10.41 & $\begin{array}{l}\text { 1-Cyclohexene-1-carboxaldehyde, } \\
\text { 2,6,6-trimethyl- }\end{array}$ & 0.15 & $\mathrm{C}_{12} \mathrm{H}_{20} \mathrm{O}$ & 180 \\
\hline 10.64 & Caryophyllene & 0.19 & $\mathrm{C}_{15} \mathrm{H}_{24}$ & 204 \\
\hline 10.73 & $\begin{array}{l}\text { Cyclohexane, } 1,5 \text {-diethenyl- } \\
\text { 3-methyl-2-methylene-, } \\
(1 \alpha, 3 \alpha, 5 \alpha) \text { - }\end{array}$ & 0.09 & $\mathrm{C}_{15} \mathrm{H}_{24}$ & 204 \\
\hline 10.90 & trans- $\alpha$-Bergamotene & 0.40 & $\mathrm{C}_{12} \mathrm{H}_{20} \mathrm{O}$ & 180 \\
\hline 11.55 & $\begin{array}{l}\text { 1,3,6,10-Dodecatetraene, } \\
\text { 3,7,11-trimethyl-, (Z,E)- }\end{array}$ & 0.15 & $\mathrm{C}_{15} \mathrm{H}_{24}$ & 204 \\
\hline 12.89 & $\begin{array}{l}\text { Naphthalene, 1,2,3,5,6,8a-hexahy- } \\
\text { dro-4,7-dimethyl-1-(1-methyleth- } \\
\text { yl)-, (1S-cis)- }\end{array}$ & 0.02 & $\mathrm{C}_{15} \mathrm{H}_{24}$ & 204 \\
\hline 15.11 & Neoisolongifolene & 0.48 & $\mathrm{C}_{15} \mathrm{H}_{26} \mathrm{O}$ & 222 \\
\hline 15.85 & Alloaromadendrene & 0.07 & $\mathrm{C}_{15} \mathrm{H}_{24}$ & 204 \\
\hline 15.98 & 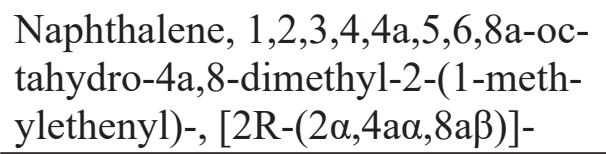 & 0.05 & $\mathrm{C}_{15} \mathrm{H}_{24}$ & 204 \\
\hline
\end{tabular}

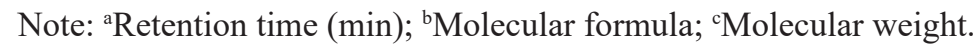


Table 3. Continued.

\begin{tabular}{|c|c|c|c|c|}
\hline $\mathbf{R T}^{\mathbf{a}}$ & Chemical compositions & $\begin{array}{c}\text { \%of total } \\
\text { area }\end{array}$ & $\mathbf{M F}^{\mathbf{b}}$ & $\mathbf{M W}^{\mathbf{c}}$ \\
\hline \multicolumn{5}{|c|}{ Cassia oil } \\
\hline 8.03 & Cinnamaldehyde, (E)- & 99.13 & $\mathrm{C}_{9} \mathrm{H}_{8} \mathrm{O}$ & 132 \\
\hline 9.68 & $\alpha$-Cubebene & 0.19 & $\mathrm{C}_{15} \mathrm{H}_{24}$ & 204 \\
\hline 9.79 & $\begin{array}{l}\text { Naphthalene, 1,2,4a,5,6,8a-hexa- } \\
\text { hydro-4,7-dimethyl-1-(1-methy- } \\
\text { lethyl)- }\end{array}$ & 0.11 & $\mathrm{C}_{15} \mathrm{H}_{24}$ & 204 \\
\hline 11.17 & Acetic acid, cinnamyl ester & 0.07 & $\mathrm{C}_{11} \mathrm{H}_{12} \mathrm{O}_{2}$ & 176 \\
\hline 12.81 & $\begin{array}{l}\text { 3-Methyl-7,8-dihydroquino- } \\
\text { lin-5(6H)-one }\end{array}$ & 0.40 & $\mathrm{C}_{10} \mathrm{H}_{11} \mathrm{NO}$ & 161 \\
\hline 13.13 & 2-Propenal, 3-(2-methoxyphenyl)- & 0.10 & $\mathrm{C}_{10} \mathrm{H}_{10} \mathrm{O}_{2}$ & 162 \\
\hline
\end{tabular}

Note: ${ }^{a}$ Retention time (min); ${ }^{b}$ Molecular formula; ${ }^{\mathrm{c}}$ Molecular weight.

\section{DISCUSSION}

Nitric oxide (NO) is a free radical which produced during inflammatory processes by inducible nitric oxide synthase (iNOS) in macrophage cells. In general, NO functions in the regulation of defense responses against various pathogens (Joo et al., 2014). The excessive production of NO is found in chronic inflammation. The high concentration of NO reacts with oxygen and superoxide to produce peroxynitrite $\left(\mathrm{ONOO}^{-}\right)$. Peroxynitrite is a powerful oxidant which reacts with proteins, lipids and DNA. The reaction of peroxynitrite induces oxidative and nitrosative changes in lipids resulting in peroxidation and DNA damage (Islam et al., 2015).

In general, nitric oxide scavengers compete with oxygen and decrease the $\mathrm{NO}$ production. The $\mathrm{NO}$ concentration is determined as nitrite $\left(\mathrm{NO}_{2}^{-}\right)$concentration which is a stable and a nonvolatile breakdown product of NO by using the Griess reagent kit. The experimental results demonstrated the ability of anise oil, lemongrass oil and cassia oil in scavenging NO free radical. These spice essential oils decreased nitrite formation from sodium nitroprusside (SNP), the nitric oxide donor. Therefore, anise oil, lemongrass oil and cassia oil may stand as NO scavenger. Especially, anise oil and lemongrass oil significantly reduced $\mathrm{NO}_{2}$ - to achieve the NO scavenging performance which is remarkable as antioxidant agents.

In addition, macrophages produce inflammatory mediators, including NO in response to LPS. NO plays important roles in the inflammatory response. 
However, the overproduction of NO can lead to cytotoxicity and chronic inflammation (Dzoyem et al., 2015). The unnecessary NO and inflammatory mediators are produced by continuously activated macrophages in chronic inflammatory processes. Chronic inflammation is associated with disease of cardiovascular, neurodegenerative disease and cancer (Okin \& Medzhitov., 2012). Consequently, macrophage has been recognized as a target of anti-inflammatory treatment.

Anise oil, lemongrass oil and cassia oil also presented NO inhibitory effect on LPS-stimulated macrophage cells. In this current research, anise oil, lemongrass oil and cassia oil effectively inhibited the NO production in macrophage. However, either lemongrass oil- or cassia oil-treated cell presented cytotoxicity in the macrophage cells when the concentration reached gather than $25 \mu \mathrm{g} / \mathrm{ml}$ while anise oil presented non-cytotoxicity although the concentration reached to $100 \mu \mathrm{g} / \mathrm{ml}$. Therefore, it's interesting that anise oil, lemongrass oil and cassia oil may be considered as an effective anti-inflammatory agent when applies in appropriate concentration to inhibit nitric oxide production from activated macrophage cells.

The cellular anti-inflammatory in macrophage cells of lemongrass oil in this current research according to previous study where lemongrass oil is presented anti-inflammatory activity in human fibroblast cells (Xuesheng and Parker, 2017). Lemongrass oil also presented anti-inflammatory in the animal model research where reduced skin inflammation in mice (Boukhatem et al., 2014). These results confirm that anti-inflammatory activity of lemongrass oil.

Cassia oil exhibits higher nitric oxide inhibition performance in activated macrophage to present anti-inflammatory property. Cassia oil has been reported the anti-inflammatory property as well as its main active compound, cinamaldehyde. Both of cassia oil and cinnamaldehyde suppressed NO and proinflammatory cytokine production in activated macrophage. The previous study demonstrated that cassia oil and cinnamaldehyde inhibited IL-1 $\beta$, IL-6, TNF- $\alpha$, MCP-1, MIP1- $\alpha$ and COX-2 and PGES- 1 expression in activated J774A. 1 macrophage cell at a concentration of $1-20 \mu \mathrm{g} / \mathrm{ml}$ and revealed noncytotoxicity to the cells by these concentrations (Pannee et al., 2014). This current study confirms that the inhibition of NO production in LPS-stimulated RAW264.7 macrophage cells to indicate anti-inflammatory property of cassia oil.

Chronic inflammation is also presented to link with different stages of cancer development, including stage of initiation, promotion, malignant conversion, invasion and metastasis (Grivennikov et al., 2010). As well as NO has been reported dual effects in both tumor growth promotion and tumoricidal effects. NO is the secondary messenger in signaling processes of cell apoptosis. In the other way, NO is involved in the invasive stage of cancer 
development. NO obtained from chronically inflamed tissue may lead to carcinogenesis. Previous studies found that inflammation posed a risk factor of colorectal cancer progression. The overexpression of iNOS, an enzyme generates NO production, was found to contribute progression of colon cancer (Wenzel et al., 2003). In addition, chronic inflammation-derived NO causes human colonic adenoma cell alteration into adenocarcinoma cells (Tazawa et al., 2013). Therefore, scavenging of nitric oxide formation and inhibition of nitric oxide production in macrophage are proposed to suppress chronic inflammation which may also useful in suppression of cancer development.

This study also displayed the cytotoxic effect of lemongrass oil and cassia oil on HT-29 human colorectal cancer cells. Lemongrass oil and cassia oil significantly reduced cell viability of HT-29 human colorectal cancer cells at concentrations of 25,50 and $100 \mu \mathrm{g} / \mathrm{ml}$ and $12.5,25,50$ and $100 \mu \mathrm{g} / \mathrm{ml}$, respectively. These results suggested that lemongrass oil and cassia oil may involve in suppression of human colorectal cancer by inhibiting the factor of cancer progression and cytotoxic directly to the cells.

In addition, this current research provided an appropriate concentration of lemongrass oil and cassia oil were to be used for further study. Lemongrass oil- and cassia oil-treated cells can achieve high cytotoxicity performance in human colorectal cancer cells, however, it's also against macrophage cell viability. Consequently, it may concern of use for avoidance of normal cell cytotoxicity.

Findings from several studies in anticancer of lemongrass oil has been reported cytotoxicity in several cancer cells, such as anti-proliferative effect on human colon carcinoma (HCT-116), breast carcinoma (MCF-7 and MDAMB 231), ovarian carcinoma (SKOV-3 and COAV) (Halabi \& Sheikh, 2014) and HeLa and ME-180 cervical cell line (Ghosh, 2013). As well as cassia oil and cinnamaldehyde were also reported cytotoxicity in some cancer cells, such as human oral squamous cell carcinoma (HSC-3) (Chang et al., 2017), head and neck squamous cell carcinoma (FaDu, Detroit-562 and Scc-25 cells) (Yang et al., 2015). Furthermore, the derivative of cinnamaldehyde, 2'-hydrocycinnamaldehyde has been reported the growth inhibition effect on SW620 colon cancer cell via inactivation of AP-1 signaling (Lee et al., 2007). The results from this research extend to present anticancer property of lemongrass oil and cassia oil in another cancer cell, HT-29 human colorectal cancer.

The present research showed that anise oil contains mainly anethole 95.72\% according to previous study which reported in Aly et al. (2016). Furthermore, this current study also showed that lemongrass oil contains mainly citral and $\beta$-citral $47.91 \%$ and $44.90 \%$, respectively as well as that was found in Katsukawa et al. (2010). In addition, cassia oil in this research contains 
mainly cinnamaldehyde $99.13 \%$ as well as those was found in previous study (Pannee et al., 2014). The variation of the main compound in each study may be due to difference in parts of the plant, geographical region, ages of the plant, harvest seasons, and method of oil extraction.

\section{CONCLUSION}

This experimental research has evaluated nitric oxide inhibition property of variable concentrations of anise oil, lemongrass oil and cassia oil through scavenging ability of NO free radical and inhibition of NO production in the LPS-stimulated RAW264.7 macrophage cells and cell viability; and the cytotoxicity through the reduction of the cell viability of HT-29 human colorectal cancer cells; and identified the compositions. The experimental results revealed that the scavenging performance was presented higher capacity in anise oil and lemongrass oil, respectively. While the inhibition of NO production (presented as the nitrate concentrations) in the LPS-stimulated macrophage cells was presented in anise oil-, lemongrass oil- and cassia oil-treated RAW264.7 macrophage cells. The non-cytotoxicity in macrophage cell is presented in all concentration of anise oil $(6.25-100 \mu \mathrm{g} / \mathrm{ml})$ and a concentration of $6.25,12.5$ and $25 \mu \mathrm{g} / \mathrm{ml}$ of lemongrass oil and cassia oil. The cytotoxicity in HT-29 human colorectal cancer cells is presented at a concentration of $12.5,25,50$ and $100 \mu \mathrm{g} / \mathrm{ml}$ where the cell viability of the treated cell was reduced different from the control. The HT-29 cytotoxicity was presented a higher performance in cassia oil- and lemongrass oil-treated cell. These results suggested that the concentration of lemongrass oil and cassia oil above $25 \mu \mathrm{g} / \mathrm{ml}$ may impact to the normal cells (presented cytotoxicity in macrophage cells). Furthermore, the experimental results revealed that the main compound of anise oil, lemongrass oil and cassia oil were anethole, citral and cinnamaldehyde, respectively. The findings demonstrate the usefulness of spices containing essential oils as radical scavenger, anti-inflammatory agents and herbbased anticancer pharmaceuticals targeting the inhibition of NO production.

\section{ACKNOWLEDGEMENTS}

The authors would like to deep gratitude to Thai Traditional Medicine College, Rajamangala University of Technology Thanyaburi (RMUTT) and the Department of Pharmacology, Faculty of Medicine, Chulalongkorn University for funding and laboratory support. Appreciation also goes to Assistant Professor Dr. Wacharee Limpanasitthikul, for her kindly advices. 


\section{REFERENCES}

Adukwu, E.C., Bowles, M., Edwards-Jones, V., and Bone, H. 2016. Antimicrobial activity, cytotoxicity and chemical analysis of lemongrass essential oil (Cymbopogon flexuosus) and pure citral. Applied Microbiology and Biotechnology. 100(22):9619-9627.https://doi.org/10.1007/s00253-0167807-y

Aly, S., Sabry, B., Shaheen, M., and Hathout, A. 2016. Assessment of antimycotoxigenic and antioxidant activity of star anise (Illicium verum) in vitro. Journal of the Saudi Society of Agricultural Sciences. 15: 20-27. https://doi.org/10.1016/j.jssas.2014.05.003

Boukhatem, M.N., Ferhat, M.A., Kameli, A., Saidi, F., and Kebir, H.T. 2014. Lemon grass (Cymbopogon citratus) essential oil as a potent antiinflammatory and antifungal drugs. Libyan Journal of Medicine. 9. https://doi.org/10.3402/ljm.v9.25431

Chang, W.L., Cheng, F.C., Wang, S.P., Chou, S.T., and Shih, Y. 2017. Cinnamomum cassia essential oil and its major constituent cinnamaldehyde induced cell cycle arrest and apoptosis in human oral squamous cell carcinoma HSC-3 cells. Environmental Toxicology. 32(2): 456-468. https://doi.org/10.1002/tox.22250

Cheng, H.W., Wang, L., Mollica, M., Re, A.T., Wu, S.Y., and Zuo, L. 2014. Nitric oxide in cancer metastasis. Cancer Letters. 353(1): 1-7. https:// doi.org/10.1016/j.canlet.2014.07.014

Choudhari, S.K., Chaudhary, M., Bagde, S., Gadbail, A.R., and Joshi, V. 2013. Nitric oxide and cancer: A review. World Journal of Surgical Oncology. 11: 118. https://doi.org/10.1186/1477-7819-11-118

Dzoyem, J.P., Tsamo, A.T., Melong, R., Mkounga, P., Nkengfack, A.E., McGaw, L.J., and Eloff, J.N. 2015. Cytotoxicity, nitric oxide and acetylcholinesterase inhibitory activity of three limonoids isolated from Trichilia welwitschii (Meliaceae). Biological Research. 48: 57. https://doi.org/10.1186/s40659-015-0049-0

Geng, S.L., Cui, Z.X., Huang, X.C., Chen, Y.F., Xu, D., and Xiong, P. 2011. Variations in essential oil yield and composition during Cinnamomum cassia bark growth. Industrial Crops and Products. 33(1): 248-252. https://doi.org/10.1016/j.indcrop.2010.10.018

Ghosh, K. 2013. Anticancer effect of lemongrass oil and citral on cervical cancer cell lines. Pharmacognosy Communications. 3(4): 41-48. https://doi.org/10.5530/pc.2013.4.6

Grivennikov, S.I., Greten, F.R., and Karin, M. 2010. Immunity, inflammation, and cancer. Cell.140(6): 883-899. https://doi.org/10.1016/j.cell.2010.01.025 
Halabi, M.F., and Sheikh, B.Y. 2014. Anti-proliferative effect and phytochemical analysis of Cymbopogon citratus extract. BioMed Research International. 2014: 906239. http://dx.doi.org/10.1155/2014/906239

Islam, B.U., Habib, S., Ahmad, P., Allarakha, S., Moinuddin, and Ali, A. 2015. Pathophysiological role of peroxynitrite induced DNA damage in human diseases: A special focus on poly (ADP-ribose) polymerase (PARP). Indian Journal of Clinical Biochemistry. 30(4): 368-385. https://doi.org/10.1007/s12291-014-0475-8

Joo, T., Sowndhararajan, K., Hong, S., Lee, J., Park, S.Y., Kim, S., and Jhoo, J.W. 2014. Inhibition of nitric oxide production in LPS-stimulated RAW 264.7 cells by stem bark of Ulmus pumila L. Saudi Journal of Biological Sciences. 21(5): 427-435. https://doi.org/10.1016/j.sjbs.2014.04.003

Katsukawa, M., Nakata, R., Takizawa, Y., Hori, K., Takahashi, S., and Inoue, H. 2010. Citral, a component of lemongrass oil, activates PPAR alpha and gamma and suppresses COX-2 expression. Biochimica Et Biophysica Acta-Molecular and Cell Biology of Lipids. 1801(11): 1214-1220. https://doi.org/10.1016/j.bbalip.2010.07.004

Kavanaugh, N.L., and Ribbeck, K. 2012. Selected antimicrobial essential oils eradicate Pseudomonas spp. and Staphylococcus aureus biofilms. Applied and Environmental Microbiology. 78(11): 4057-4061. https:// doi.org/10.1128/AEM.07499-11

Lee, C.W., Lee, S.H., Lee, J.W., Ban, J.O., Lee, S.Y., Yoo, H.S., and Hong, J.T. 2007. 2-Hydroxycinnamaldehyde inhibits SW620 colon cancer cell growth through AP-1 inactivation. Journal of Pharmacological Sciences.104(3): 284-284.

Lee, H.S., Kim, S.Y., Lee, C.H., and Ahn, Y.J. 2004. Cytotoxic and mutagenic effects of Cinnamomum cassia bark-derived materials. Journal of Microbiology and Biotechnology.14(6): 1176-1181.

Lee, S.H., Lee, S.Y., Son, D.J., Lee, H., Yoo, H.S., Song, S.G., and Hong, J.T. 2005. Inhibitory effect of 2'-hydroxycinnamaldehyde on nitric oxide production through inhibition of NF-kappa B activation in RAW 264.7 cells. Biochemical Pharmacology. 69(5): 791-799.

Liakos, I.L., Abdellatif, M.H., Innocenti, C., Scarpellini, A., Carzino, R., Brunetti, V., and Pompa, P.P. 2016. Antimicrobial lemongrass essential oil-copper ferrite cellulose acetate nanocapsules. Molecules. 21(4): 520.https://doi.org/10.3390/molecules21040520

Lin, C.C., Wu, S.J., Chang, C.H., and Ng, L.T. 2003. Antioxidant activity of Cinnamomum cassia. Phytotherapy Research. 17(7): 726-730. https:// doi.org/10.1002/ptr.1190 
Matan, N., Matan, N., and Ketsa, S. 2012. Effect of heat curing on antifungal activities of anise oil and garlic oil against Aspergillus niger on rubberwood. International Biodeterioration \& Biodegradation. 75: 150-157. https://doi.org/10.1016/j.ibiod.2012.03.012

Okin, D., and Medzhitov, R. 2012. Evolution of inflammatory diseases. Current Biology. 22(17): R733-740. https://doi.org/10.1016/j.cub.2012.07.029

Ooi, L.S. M., Li, Y.L., Kam, S.L., Wang, H., Wong, E.Y.L., and Ooi, V.E.C. 2006. Antimicrobial activities of cinnamon oil and cinnamaldehyde from the Chinese medicinal herb Cinnamomum cassia Blume. American Journal of Chinese Medicine. 34(3): 511-522. https://doi.org/10.1142/ S0192415X06004041

Pannee, C., Chandhanee, I., and Wacharee, L. 2014. Antiinflammatory effects of essential oil from the leaves of Cinnamomum cassia and cinnamaldehyde on lipopolysaccharide-stimulated J774A.1 cells. Journal of Advanced Pharmaceutical Technology \& Research. 5(4):164-170. https://doi.org/10.4103/2231-4040.143034

Rahamooz-Haghighi, S., and Asadi, M. 2016. Anti-proliferative effect of the extracts and essential oil of Pimpinella anisum on gastric cancer cells. Journal of Herbmed Pharmacology. 5: 157-161.

Reuter, S., Gupta, S.C., Chaturvedi, M.M., and Aggarwal, B.B. 2010. Oxidative stress, inflammation, and cancer: How are they linked? Free Radical Biology and Medicine. 49(11): 1603-1616. https://doi.org/10.1016/ j.freeradbiomed.2010.09.006

Swamy, M.K., Akhtar, M.S., and Sinniah, U.R. 2016. Antimicrobial properties of plant essential oils against human pathogens and their mode of action: An updated review. Evidence-Based Complementary and Alternative Medicine. 2016: Article ID 3012462. http://dx.doi.org/ $10.1155 / 2016 / 3012462$

Tazawa, H., Kawaguchi, T., Kobayashi, T., Kuramitsu, Y., Wada, S., Satomi, Y., and Okada, F. 2013. Chronic inflammation-derived nitric oxide causes conversion of human colonic adenoma cells into adenocarcinoma cells. Experimental Cell Research. 319(18): 2835-2844. https://doi.org/ 10.1016/j.yexcr.2013.08.006

Wenzel, U., Kuntz, S., de Sousa, U.J., and Daniel, H. 2003. Nitric oxide suppresses apoptosis in human colon cancer cells by scavenging mitochondrial superoxide anions. International Journal of Cancer. 106(5): 666-675. https://doi.org/10.1002/ijc.11294

Xuesheng, H., and Parker, T.L. 2017. Lemongrass (Cymbopogon flexuosus) essential oil demonstrated anti-inflammatory effect in pre-inflamed human dermal fibroblasts. Biochimie Open. 4: 107-111. https://doi.org/ 10.1016/j.biopen.2017.03.004 
Yang, C.H., Li, R.X., and Chuang, L.Y. 2012. Antioxidant activity of various parts of cinnamomum cassia extracted with different extraction methods. Molecules. 17(6):7294-7304.https://doi.org/10.3390/molecules 17067294

Yang, X.Q., Zheng, H., Ye, Q., Li, R.Y., and Chen, Y. 2015. Essential oil of Cinnamon exerts anti-cancer activity against head and neck squamous cell carcinoma via attenuating epidermal growth factor receptor-tyrosine kinase. Journal of the Balkan Union of Oncology. 20(6): 1518-1525. 